\title{
MENINGKATKAN KOMPETENSI PELAKU UMKM DALAM BERBISNIS MELALUI PELATIHAN HARGA POKOK PRODUKSI
}

\author{
Marieta Ariani \\ Fakultas Ekonomi dan Bisnis Universitas Trisakti \\ marieta@trisakti.ac.id \\ Hasnawati Zainal \\ Fakultas Ekonomi dan Bisnis Universitas Trisakti \\ hasnawati@trisakti.ac.id
}

\section{Info Artikel}

Diterima:

04-11-2021

Direvisi:

24-12-2021

Diterbitkan:

24-12-2021

\begin{abstract}
The success of the company in determining the Selling Price of its business products is largely determined by the success of the company in determining or calculating the Cost of Production (HPP) of the products it produces.Errors in the determination of the cost of production (HPP) can cause errors in the determination of the selling price of the resulting product, so that the company cannot compete with other similar businesses. The difficulty of determining the cost of production and selling prices of fashion and culinary products experienced by MSME entrepreneurs has become a big problem and has been going on for a long time among kompeten member entrepreneurs in Bekasi, so continuous training is needed. This can also be used as a background or basis for scientific research by PKM lecturers, so that research results can be obtained that can answer the difficulties of entrepreneurs of KOMPETeN members of the Bekasi region in determining the cost of production and selling prices of fashion and culinary products.
\end{abstract}

Keywords: UMKM, Cost of Goods Manufactured

DOI: $10.29303 /$ abdimassangkabira.v2i1.68

\section{Pendahuluan}

Kebutuhan hidup yang semakin meningkat di Indonesia menuntut masyarakat untuk dapat mengembangkan perekonomian di dalam keluarga.Beberapa hal telah berubah dari waktu ke waktu untuk memenuhi kebutuhan pangsa pasar, serta kebutuhan masyarakat itu sendiri. Salah satu yang berubah adalah keberadaan sektor UMKM yang menggerakkan perekonomian masyarakat. Selain itu, sektor ini bersinggungan langsung 
dengan sektor lain sehingga kelangsungan usaha berjalan dengan baik. Perkembangan UMKM di indonesia sangat pesat. Dalam perekonomian Indonesia, Usaha Mikro, Kecil, dan Menengah (UMKM) adalah kelompok usaha yang memiliki jumlah paling besar. UMKM memiliki peran yang sangat penting dan strategis dalam mendukung pembangunan ekonomi bangsa. Peran tersebut antara lain (1) status sebagai pemain utama dalam kegiatan ekonomi di berbagai sektor, (2) pemberi kerja terbesar , (3) pemain utama dalam mengembangkan kegiatan ekonomi daerah dan penguatan masyarakat, (4) menciptakan pasar baru dan sumber inovasi, serta (5 Kontribusinya untuk Mempertahankan Neraca Pembayaran Melalui Kegiatan Ekspor (Undang-Undang, Nomor. 20: 2008).

Adanya komunitas yang dibentuk oleh ibu - ibu rumah tangga di suatu lingkungan adalah salah satu bentuk pemberdayaan perempuan dilingkup keluarga. Komunitas ibu-ibu rumah tangga ini dapat membantu memunculkan suatu usaha mikro yang kreatif dan inovatif, sehingga pendapatan rumah tangga di lingkungan tersebut dapat meningkat. Salah satu lingkungan atau daerah yang membentuk komunitas ibu - ibu rumah tangga adalah Komunitas Perempuan Tangguh Nasional (KOMPETeN) yang bertempat di Grand Mall Bekasi Lt 2, No. 1 Jalan Jend Sudirman 17144 Bekasi. Komunitas Perempuan Tangguh Nasional (KOMPETeN) adalah suatu wadah komunitas untuk ibu-ibu rumah tangga yang memiliki wirausaha, dengan tujuan untuk membantu mengembangkan semangat kewirausahaan, memperkuat peran perempuan di UMKM, membuka akses perijinan serta pelatihan untuk mengembangkan UMKM, membuka akses pemasaran secara global, dan menciptakan sinergi di antara sesama anggota serta anggota dan pihak lain.

Masalah yang dihadapi oleh anggota komunitas KOMPETeN adalah mereka belum mampu untuk menghitung harga pokok dari produk yang mereka olah untuk dijual, sehingga mereka belum dapat menentukan harga jual produk mereka yang mengakibatkan keuntungan yang didapat dari hasil penjualan produk kurang maksimal. Kurangnya kompetensi di dalam menghitung harga pokok produk disebabkan oleh kurangnya pemahaman mengidentifikasi biaya, yang mengakibatkan biaya-biaya seperti biaya penyusutan dan biaya tenaga kerja tidak diikutsertakan dalam perhitungan biaya produk yang ditanggung oleh pemilik (Nurlela \& Rangkuti, 2017). Selama ini pelaku UMKM hanya menetapkan harga jual sesuai dengan harga pasar dan tidak mengikuti prosedur akuntansi untuk menghitung biayabiaya yang dikeluarkan selama proses manufaktur secara detail (Prabowo, 2019). Harga pokok produksi menurut Horngren (2018) adalah biaya barang yang dibeli untuk diproses sampai selesai, baik sebelum maupun selama periode akuntansi berjalan. Informasi yang diperlukan mengenai biaya yang membentuk harga pokok produksi meliputi biaya bahan baku, biaya tenaga kerja dan biaya overhead. 


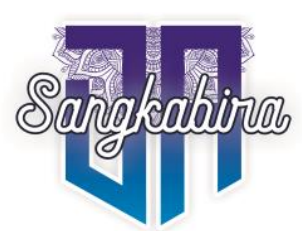

Vol. 2, No. 1, Desember 2021

Kegiatan PKM ini bertujuan untuk memberikan pemahaman dan kemampuan untuk mengidentifikasi biaya bahan baku langsung,biaya tenaga kerja, dan biaya overhead, serta melakukan perhitungan harga pokok produk yang dimiliki oleh UMKM. Secara rinci, setelah penyuluhan dan pelatihan ini para pelaku UMKM mampu (1) memahami konsep harga pokok produk (2) memahami cara mengidentifikasi biaya bahan baku langsung,biaya tenaga kerja, dan biaya overhead (3) melakukan perhitungan harga pokok produk.

Tabel 1. Tahap Pra Pelaksanaan Kegiatan

\begin{tabular}{ll}
\hline Survei & $15-20$ Oktober 2020 \\
\hline $\begin{array}{l}\text { Rapat Pertama dan Koordinasi } \\
\text { dengan UMKM KOMPETeN }\end{array}$ & 30 Oktober 2020 \\
\hline $\begin{array}{l}\text { Koordinasi dengan pemberi materi } \\
\text { dan UMKM KOMPETeN }\end{array}$ & 5 Maret 2021 \\
\hline Penyusunan Modul & $9-15$ Maret 2021 \\
\hline Pelaksanaan Pelatihan & 16 Maret 2021 \\
\hline $\begin{array}{l}\text { Pendampingan dan Evaluasi } \\
\text { Pembuatan Laporan }\end{array}$ & April-Juni 2021 \\
\hline
\end{tabular}

Metode yang digunakan di dalam pelaksanaan kegiatan ini adalah pelatihan perhitungan harga pokok produksi disertai pendampingan berkelanjutan berupa konsultasi jika peserta menenemui kesulitan di dalam menghitung harga pokok produk. Peserta yang ikut dalam kegiatan PKM adalah ibu-ibu pelaku UMKM dibidang fashion dan kuliner yang tergabung dalam komunitas KOMPETeN di Bekasi. Pelatihan ini penting bagi ibu-ibu pelaku UMKM dibidang fashion dan kuliner karena mereka yang menentukan berapa harga jual per item barang seperti kue ataupun baju.

Pelaksanaan kegiatan dilakukan pada tanggal 16 Maret 2021 pada pukul $08.00 \mathrm{~s} / \mathrm{d} 12.00$ WIB melalui media online zoom meeting, dengan peserta sebanyak 21 (dua puluh satu) orang. Materi pelatihan dipaparkan oleh Tim Dosen Prodi D III Perpajakan FEB Universitas Trisakti. Pelaksanaan pelatihan dibantu oleh 2 (dua) orang mahasiswa Prodi D III Perpajakan FEB Usakti. Materi pelatihan disampaikan dengan metode menjelaskan, membahas, tanya jawab dan pengisian kertas kerja praktek perhitungan HPP sesuai dengan data keuangan masing-masing peserta. PKM ini bekerja sama dengan Komunitas Perempuan Tangguh Nasional (KOMPETeN) sebagai mitra PKM, untuk membantu sosialisasi kegiatan PKM serta mengkoordinir siapa-siapa saja yang mengikuti pelatihan.

Hasil

Kegiatan pengabdian kepada masyarakat dilakukan di Komunitas Perempuan Tangguh Nasional (KOMPETeN) yang bertempat di Grand Mall Bekasi Lt 2, No. 1 Jalan Jend Sudirman 17144 Bekasi. Berdasarkan hasil pengabdian tim Fakultas Ekonomi dan Bisnis Universitas Trisakti, dapat 
dijelaskan bahwa UMKM yang memproduksi suatu barang memerlukan informasi terkait dengan jumlah biaya yang dikeluarkan. Informasi mengenai biaya bahan baku langsung ,biaya tenaga kerja langsung, dan biaya overhead diperlukan untuk dapat menghitung harga pokok produksi. Apabila pelaku UMKM dapat menetapkan haga pokok produksi dengan tepat, maka pelaku UMKM juga dapat menetukan harga jual yang wajar untuk produk yang akan dijual.

Adapun Langkah-langkah yang dilakukan dalam pelatihan perhitungan HPP adalah sebagai berikut

1. Identifikasi Biaya Bahan Baku

Pada tahap ini dilakukan identifikasi menggunakan data real dari salah satu peserta UMKM yaitu UMKM Dapur Raisa. Data yang digunakan adalah data bahan baku produksi cheesestick selama satu bulan.Bahan baku yang digunakan oleh UMKM Dapur Raisa dikelompokkan menjadi bahan baku langsung dan bahan baku tidak langsung.

\begin{tabular}{|c|c|c|c|c|c|c|}
\hline & MATERIAL & KEBUTUHAN & & BIAYA & $\begin{array}{c}\text { BIAYA } \\
\text { PERBUNGKUS }\end{array}$ & KATEGORI BIAYA \\
\hline 1 & Keju & 10 dus (uk $2 \mathrm{Kg}$ ) & $\mathrm{Rp}$ & 1.800 .000 & 4.401 & Bahan Baku Langsung \\
\hline 2 & Terigu & 25 bungkus (uk $2 \mathrm{Kg}$ ) & Rp & 360.000 & 880 & Bahan Baku Langsung \\
\hline 3 & Sagu & 2 karung (uk $25 \mathrm{Kg}$ ) & $\mathrm{Rp}$ & 360.000 & 880 & Bahan Baku Langsung \\
\hline 4 & Margarin & $15 \mathrm{Kg}$ & $\mathrm{Rp}$ & 210.000 & 513 & Bahan Baku Langsung \\
\hline 5 & Minyak & $12 \mathrm{krat}$ & $\mathrm{Rp}$ & 164.000 & 401 & Bahan Baku Langsung \\
\hline 6 & Telur & $10 \mathrm{Kg}$ & Rp & 250.000 & 611 & Bahan Baku Langsung \\
\hline 7 & Oregano & & Rp & 70.000 & 171 & Indirect Material/FOH Variable \\
\hline 8 & Kaldu Jamur & & Rp & 150.000 & 367 & Bahan Baku Langsung \\
\hline 9 & Garam & 7 bungkus & $\mathrm{Rp}$ & 49.000 & 120 & Indirect Material/FOH Variable \\
\hline & Baking Powder & 2 Kaleng & Rp & 80.000 & 196 & Indirect Material/FOH Variable \\
\hline 11 & Air & 4 galon & $\mathrm{Rp}$ & 40.000 & $\mathrm{Rp}$ & Indirect Material/FOH Variable \\
\hline
\end{tabular}

\section{Gambar 1 Identifikasi Biaya Bahan Baku}

2. Menghitung Biaya Penyusutan Overhead Tetap

Pada tahap ini dilakukan perhitungan biaya penyusutan perbulan untuk peralatan yang digunakan di dalam produksi kue cheesestick.

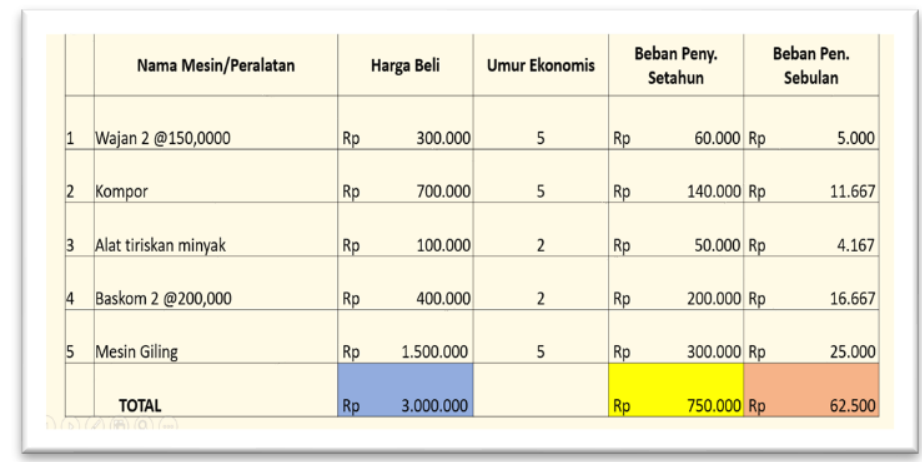

Gambar 2 Biaya Penyusutan Peralatan 


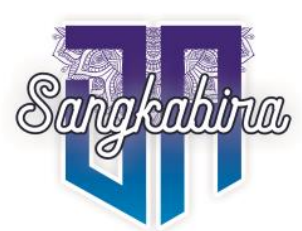

Vol. 2, No. 1, Desember 2021

3. Menghitung Biaya Overhead Tetap

Pada tahap ini dilakukan perhitungan biaya overhead tetap per bulan yang terdiri dari biaya penyusutan perbulan ditambah dengan biaya tetap lainnya seperti biaya listrik dan biaya gas tabung ukuran $12 \mathrm{~kg}$.

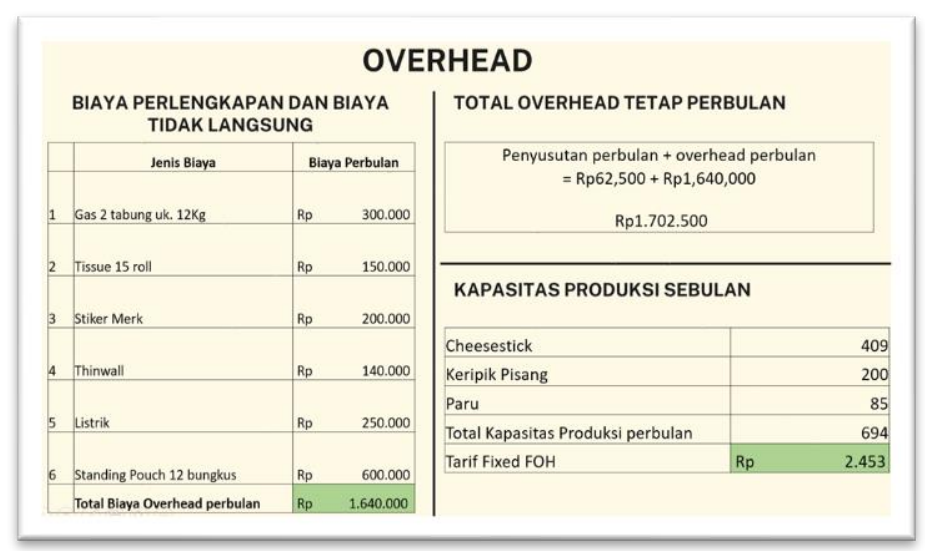

Gambar 3 Biaya Overhead Tetap

4. Menghitung Harga Pokok Produksi

Tahap terakhir yaitu menghitung harga pokok produksi yang terdiri dari penjumlahan biaya bahan baku langsung, biaya tenaga kerja langsung, dan biaya overhead.

\section{Diskusi}

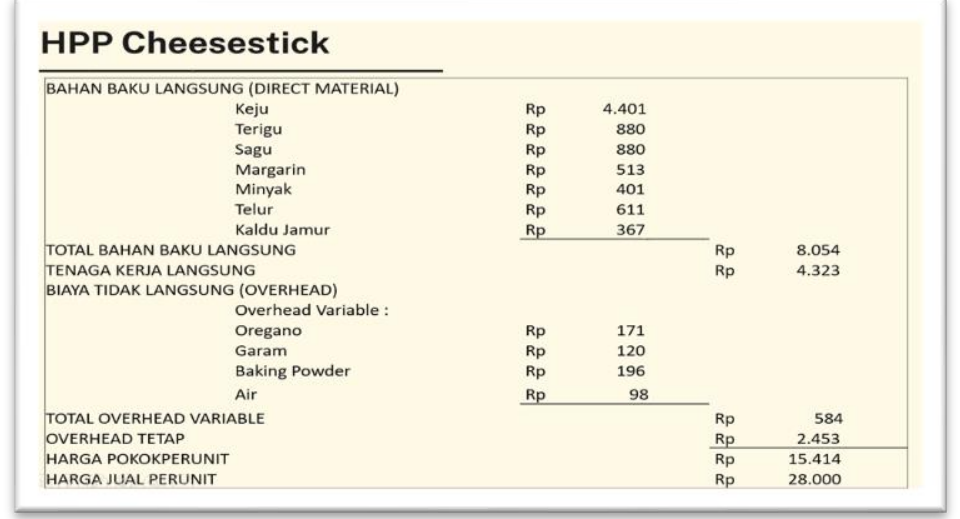

Gambar 4 Perhitungan Harga Pokok Produksi

Berdasarkan hasil komunikasi awal dengan komunitas UMKM, permasalahan yang dihadapi oleh mitra adalah mereka tidak memahami pentingnya menghitung harga pokok produksi untuk bisnis mereka, mereka tidak memiliki pengetahuan dan kemampuan untuk menghitung harga pokok produksi, pelaku UMKM didalam menentukan harga jual hanya berdasarkan harga pasar, sehingga untung atau rugi dari hasil usaha tidak dapat dihitung dengan tepat. Pemecahan masalah yang dilakukan oleh tim pengabdian adalah memberi pemahaman, pelatihan, dan pendampingan 
mengenai perhitungan harga pokok produksi dan pencatatan ke dalam jurnal, serta diakhiri dengan penyusunan laporan laba/rugi. Kegiatan PKM ini dilaksanakan untuk membantu komunitas UMKM KOMPETEN di Bekasi didalam menghitung harga pokok produksi, sehingga pelaku UMKM mampu untuk menghitung harga jual produk mereka dengan tepat dan dapat menghitung laba sesuai dengan standar akuntansi yang berlaku umum.

\section{Kesimpulan}

Berdasarkan hasil kegiatan pengabdian kepada masyarakat dapat disimpulkan bahwa pemahaman mengenai biaya-biaya yang terkait dengan biaya produksi yaitu biaya bahan baku langsung,biaya tenaga kerja langsung,dan biaya overhead sangat dibutuhkan oleh pelaku usaha UMKM. Setelah paham, mereka dapat menghitung biaya produksi dengan tepat dan menetapkan harga jual yang wajar bagi produk yang akan mereka jual.

Untuk meningkatkan kemampuan pelaku usaha UMKM, sebaiknya dilakukan pendampingan dalam proses menghitung harga pokok produk.Sehingga ketika mereka mengalami kesulitan, dapat segera terelesaikan.

\section{Pengakuan/Acknowledgements}

Ucapan terimakasih disampaikan kepada kepada:

1. Ketua dan Sekretaris Program Studi DIII Perpajakan Fakultas Ekonomi dan Bisnis (FEB) Universitas Trisakti yang telah membantu kelancaran dalam pelaksanaan pengabdian.

2. Pengurus Komunitas Perempuan Tangguh Nasional (KOMPETeN) dan Para Dosen Program Studi DIII Akuntansi Perpajakan Fakultas Ekonomi dan Bisnis (FEB) Universitas Trisakti yang telah turut berpartisipasi aktif dalam pelaksanaan kegiatan pengabdian.

3. Semua pihak yang tidak dapat kami sebutkan satu persatu yang telah membantu terlaksananya kegiatan PKM ini.

\section{Daftar Referensi}

Horngren, Charles T., Srikant M. Datar, Madhav V. Rajan, "Cost AccountingA Managerial Emphasis", 16 $6^{\text {th }}$ edition, Pearson Prentice Hall, 2018.

Nurlela, \& Rangkuti, C. (2017). Analisis Perbandingan Metode Penentuan Harga Pokok Produksi pada CV. Satu Angin Persada. Jurnal Bisnis Administrasi, 06(01), 69- 72.

Prabowo, A. A. (2019). Analisis Penentuan Harga Pokok Produksi Berdasarkan Metode Harga Pokok Pesanan (Job Order Costing) pada UD Adi Prima Karsa di Daerah Istimewa Yogyakarta. Jurnal UMKM Dewantara, 2(1), 15-25.

Undang-Undang Republik Indonesia Nomor. 20 Tahun 2008 tentang Usaha Mikro, Kecil, Dan Menengah (2008) 